\title{
Prototype mobile contactless transaction system in traditional markets to support the covid-19 physical distancing program
}

\author{
Irawan Afrianto, Mouhamad Hatta Hiroshi Sasmita, Sufa Atin \\ Department of Informatics Engineering, Universitas Komputer Indonesia, Bandung, Indonesia
}

\begin{tabular}{l} 
Article Info \\
\hline Article history: \\
Received Aug 9, 2021 \\
Revised Oct 10, 2021 \\
Accepted Oct 21, 2021 \\
\hline
\end{tabular}

\section{Keywords:}

Contactless transaction

Covid-19

Digital payment

Prototype

QR code

Traditional market

\begin{abstract}
One way to prevent and reduce the spread of the covid-19 pandemic is through physical distancing program. This research aims to develop a prototype contactless transaction system using digital payment mechanisms and $\mathrm{QR}$ code technology that will be applied in traditional markets. The method used in the development of electronic market systems is a prototype approach. The application of QR code and digital payments are used as a solution to minimize money exchange contacts that are common in traditional markets. The results showed that the system built was able to accelerate and facilitate the buying and selling transaction process in traditional market environment. Alpha testing shows that all functional systems are running well. Meanwhile, beta testing shows that the user can very well accept the system that was built. The results of the study also show acceptance of the usefulness of the system being built, as well as the optimism of its users to be able to take advantage of this system both technologically and functionally, so its can be a part of the digital transformation of the traditional market to the electronic market and has become one of the solutions in reducing the spread of the current covid-19 pandemic.
\end{abstract}

This is an open access article under the CC BY-SA license.

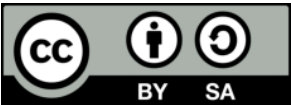

\section{Corresponding Author:}

Irawan Afrianto

Department of Informatics Engineering

Universitas Komputer Indonesia (UNIKOM)

112-116 Dipati Ukur Street, Bandung 40132, Indonesia

Email: irawan.afrianto@email.unikom.ac.id

\section{INTRODUCTION}

The development of traditional markets or people's markets has contributed greatly to increasing employment opportunities, economic growth, and people's income [1]. The number of traditional markets in Indonesia reached 14,182 units in 2018, making traditional markets one of the basic foundations for regional economies in Indonesia [2].

Traditional markets are markets that in practice are still traditional in nature where sellers and buyers can fully interact and use cash payments in their transactions. The use of cash when transacting takes more time to prepare money that fits your needs and time to wait for changes from sellers. In addition, by transacting using cash, there is the potential for the spread of various diseases, this is because viruses and bacteria can be attached to the exchange of money during the buying and selling process. In the face of Indonesia's shifting cash-to-non-cash transaction trend, a new mechanism in the conventional market environment is required to address these issues. Digital transformation can change business processes [3], provide added value, and increase productivity [4], [5] can be used as a solution to these problems. In addition, the current covid-19 virus outbreak has become a momentum for the acceleration of digital transformation with various technologies that support it [6]. Research carried out in the context of 
accelerating digital transformation in the covid-19 pandemic era includes changes in cash to non-cash transactions in cities [7], changes in education models and methods [8], [9] as well as the role of e-wallets during the covid-19 pandemic [10].

Electronic money-based digital payments in Indonesia are now starting to get the attention and trust of their users. Electronic money is a means of payment in electronic form where the value of money is stored in certain electronic media [11]. The user must first deposit the money to the publisher and keep it in electronic media before using it for transaction purposes [12]. Electronic money is divided into two types, namely e-money and e-wallet. E-money is a type of electronic money in the form of cards (chip-based). Examples of e-money products include Flazz BCA, Brizzi BRI, JakCard Bank DKI. Meanwhile, e-wallets are electronic money in the form of applications (server-based). Examples of e-wallet products include TCash, Go-Pay, OVO, etc. E-wallets are a type of electronic money that can be accessed via smartphones [13].

E-wallets allow transactions to be carried out more quickly and safely without requiring change. So, sellers can focus more on serving buyers and transaction activities are completed more quickly. In previous research with the integration of a mobile payment system with NFC, it is proven that transactions between two android smartphones can be completed quickly, namely $141.50 \mathrm{~ms}$ and transactions with NFC assistance take $270.87 \mathrm{~ms}$ [14]. In other studies on mobile payments, it is revealed that since smartphones are an inseparable part of the lives of all humans, the use of mobile payments will continue to increase in the future [15].

QR code was chosen as a medium for data interaction between two android smartphones because all smartphones have cameras. So that it allows all smartphones to interact with the data needed in transaction activities. Previous research has implemented QR code as a document licensing tool which contains important information and enables fast and safe access to that information [16]. In other studies also revealed that QR code has several advantages such as speed of access, storing more information, and the presence of pattern recognition that allows the orientation of the QR code to be scanned in all positions [17], [18]. The application of QR code technology and e-wallet payment has been implemented in areas such as public transportation where QR codes and e-Wallets are used as a substitute for travel tickets, which are paid automatically via e-wallets of passengers [19], [20]. Another application is in research [21], where QR codes are used as a substitute for tickets for parking areas and are integrated with IoT devices and digital payments. The use of QR codes and E-Wallet is also used in menu ordering and food payments at restaurants [22]. Another aspect that needs to be considered is the acceptance of the use of QR code technology and electronic payments [23], both in terms of convenience [24] and how to create a sense of trust and usefulness of this technology by users [25].

However, previous research that has been done, takes the theme of activities and environments that are easy to adapt to new technologies. Meanwhile, the research developed leads to a traditional market ecosystem, where users are ordinary people and still use traditional transactions. The aims of this research is to integrate digital payments (e-wallets) and QR code by developing a prototype non-cash transaction system which can be accessed on smartphones owned by sellers and buyers in traditional markets, as an alternative of payment that can make transactions more practical, fast and secure. Furthermore, the prototype developed will be tested as part of digital transformation in the traditional market environment, evaluated usefulness and optimism the direct impacts on intention to adopt by users, and it is hoped that it can reduce the spread of the covid-19 virus because the system used in transactions is contactless.

\section{RESEARCH METHOD}

To achieve the objectives of the research carried out, researchers used a prototyping approach. The activities carried out in this study include problem identification, communication processes, planning processes, rapid modeling and design, development processes, implementation and feedback, and finally making conclusions and recommendations. Figure 1 shows the activities of the research activities carried out. The first stage of this research is the problem identification activity, where the researcher identifies the phenomena that become the problem and the potential solutions that can be used to solve the problem. The second stage is communication, where the activity is by conducting interviews and observations, giving questionnaires and conducting literature reviews, which are intended to get a clearer picture of the problem and solutions that have been done before. The third stage is rapid planning, modeling, and design. This activity begins with a system analysis in which the process includes analysis of current conditions and analysis of system requirements to be developed, followed by system modeling, which aims to provide a functional description of the software that will be built, as well as the functional design of the system to be developed. The fourth stage of this research includes the stages of system development by coding the software using the appropriate programming language and framework, implementing and testing the system being built, and providing feedback on the system that has been built. The final stage of this research is to provide conclusions and provide recommendations from the research that has been done. 


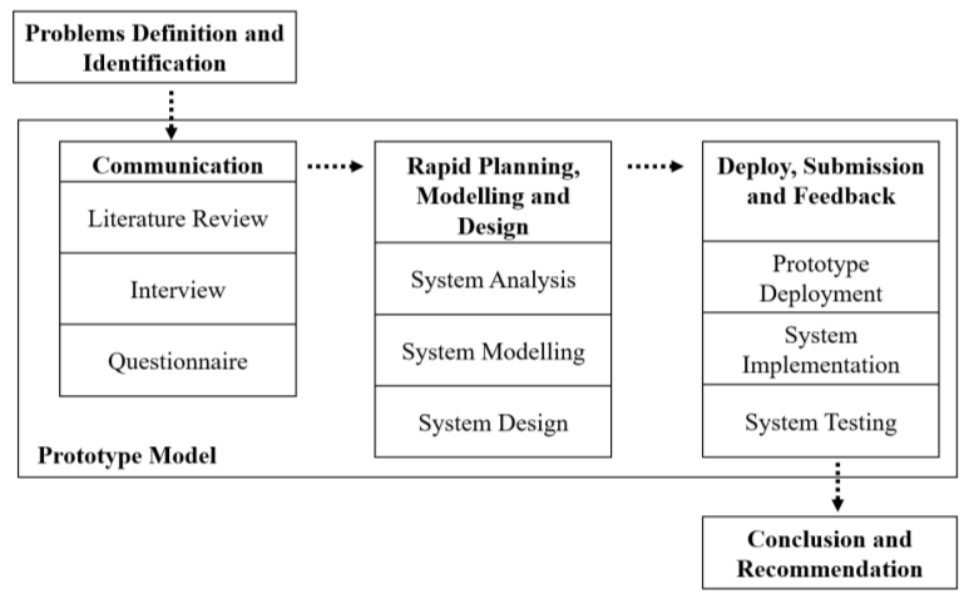

Figure 1. The research methodology

\section{RESULTS AND DISCUSSION}

\subsection{Proposed system architecture}

The modeling stage of a system is used to make it easier for system developers to translate it into the next stage. System modeling can use the rich picture mechanism as the first step towards system design [26]. The proposed system consists of frontend and backend systems. The backend is made as a websitebased application while the frontend is made as an android based application. The frontend system consists of two types of sub-systems, namely sub-systems for sellers and buyers, while the backend system is intended for market managers. As an interactive tool for the two types of frontend systems for sellers and buyers in sharing detailed shopping information on this system, QR code technology is used. And the payment instrument used in this application is the Go-Pay e-wallet from Go-Jek based on the payment gateway. The proposed system shows in Figure 2. The application involved in the transaction system architecture is the frontend application of sellers and buyers. This architecture describes a series of processes Figure 3.

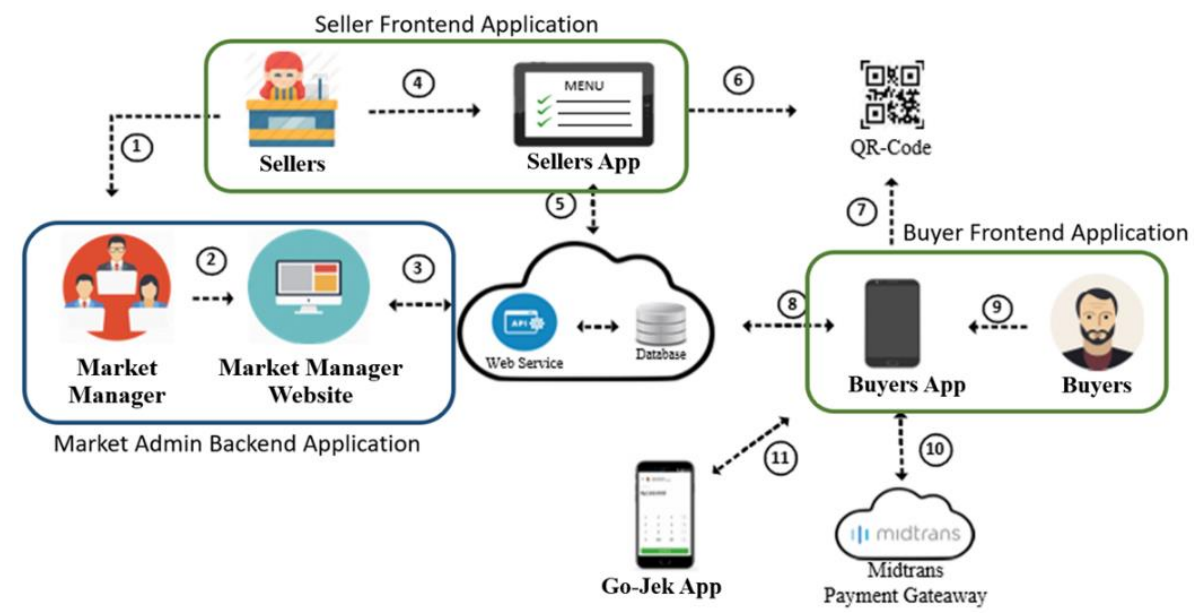

Figure 2. Proposed system architecture

Figure 3 explanation:

1) The buyer initializes the details of the shopping the buyer will buy.

2) The merchant application generates a transaction id that has been obtained from the data that has just been stored into the database into a QR-Code.

3) The buyer scans the QR-Code on the merchant's device screen using the buyer application.

4) The buyer checks the shopping details on the application.

5) The buyer makes a payment from the buyer's application.

6) The system changes the transaction status concerned to "Paid".

Prototype mobile contactless transaction system in traditional markets to support the ... (Irawan Afrianto) 


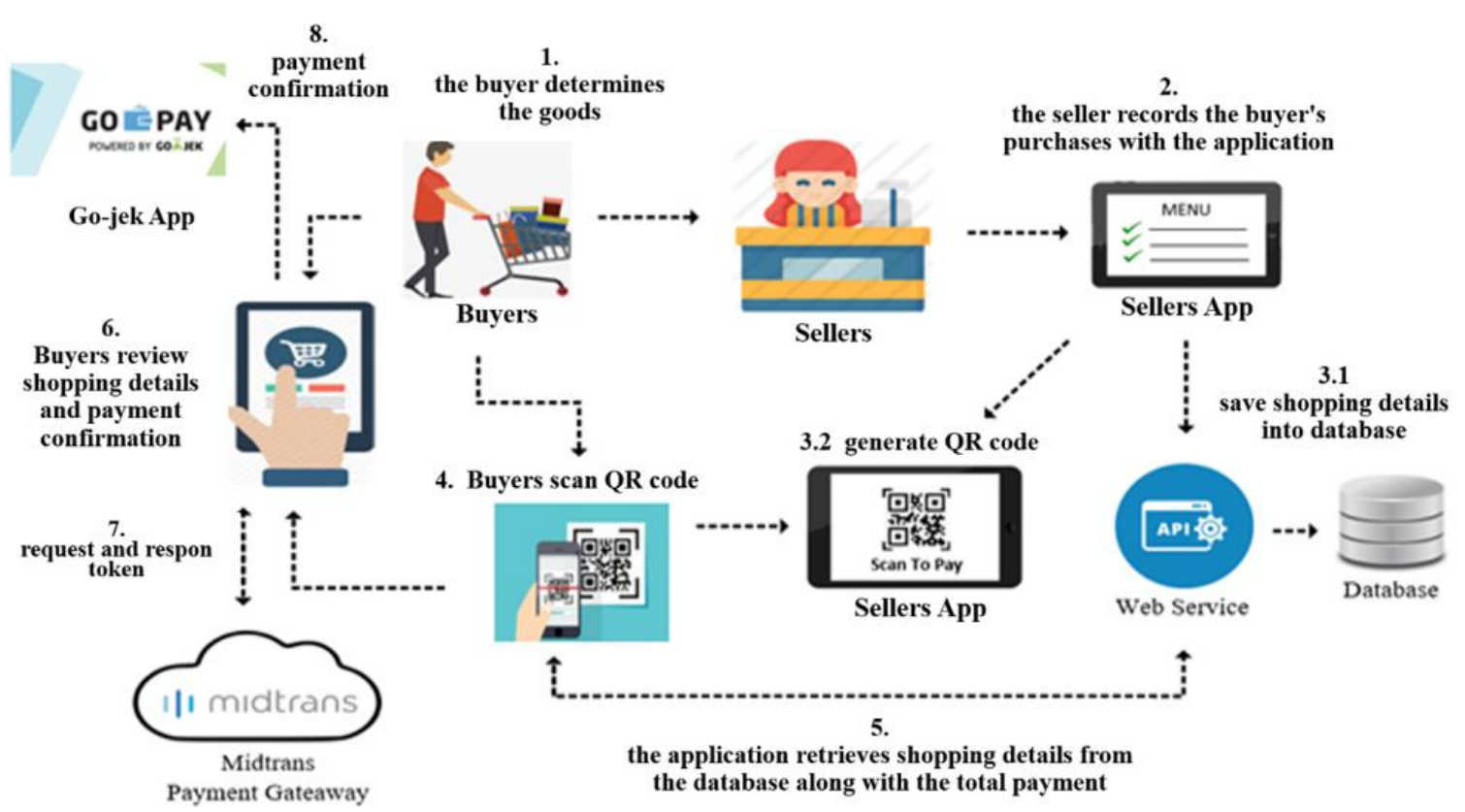

Figure 3. Transaction system architecture

\subsection{Functional requirements analysis}

Functional requirements analysis describes the process of activities that will be applied in a system and explains the requirements needed by the system for the system to run well [27]. Use case diagrams to describe an interaction between one or more actors with the system to be created. Roughly, use cases are used to find out what functions are in a system and who has the right to use these functions. Analysis of use case diagrams on the system to be built can be seen in Figure 4.

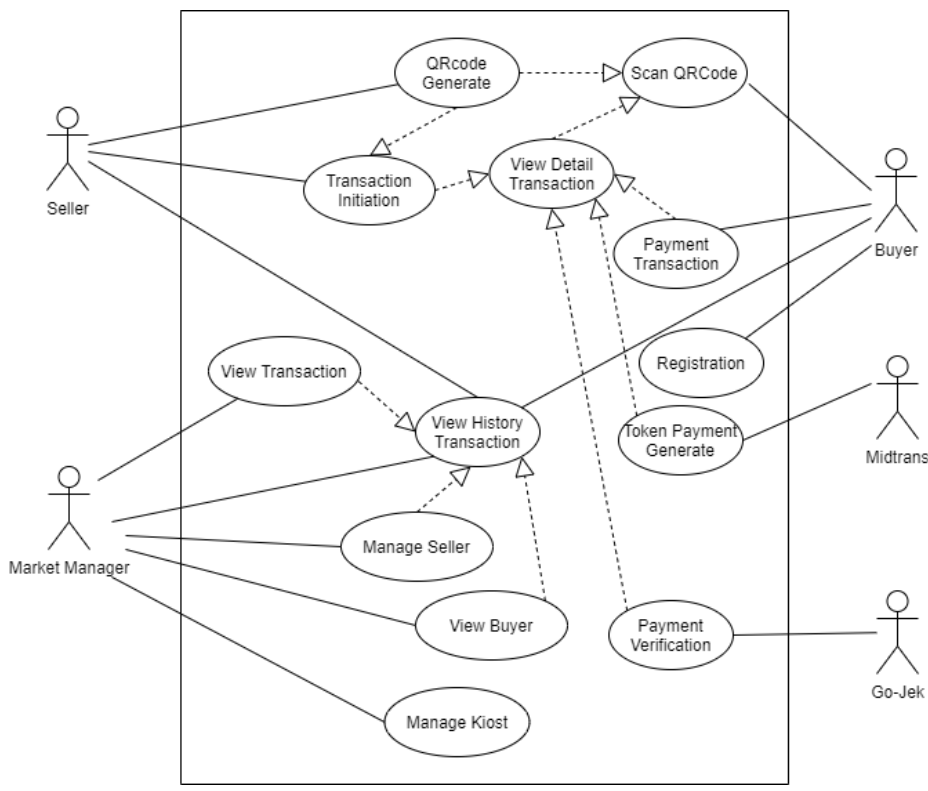

Figure 4. Use case diagram of contactless system

The QR code in this system is used as a mechanism for sending transaction IDs from the merchant application to the buyer's application. So that sellers and buyers can access the same transaction data in the 
database according to the transaction id that has been raised. A general description of how QR code works in the system is shown in Figure 5.

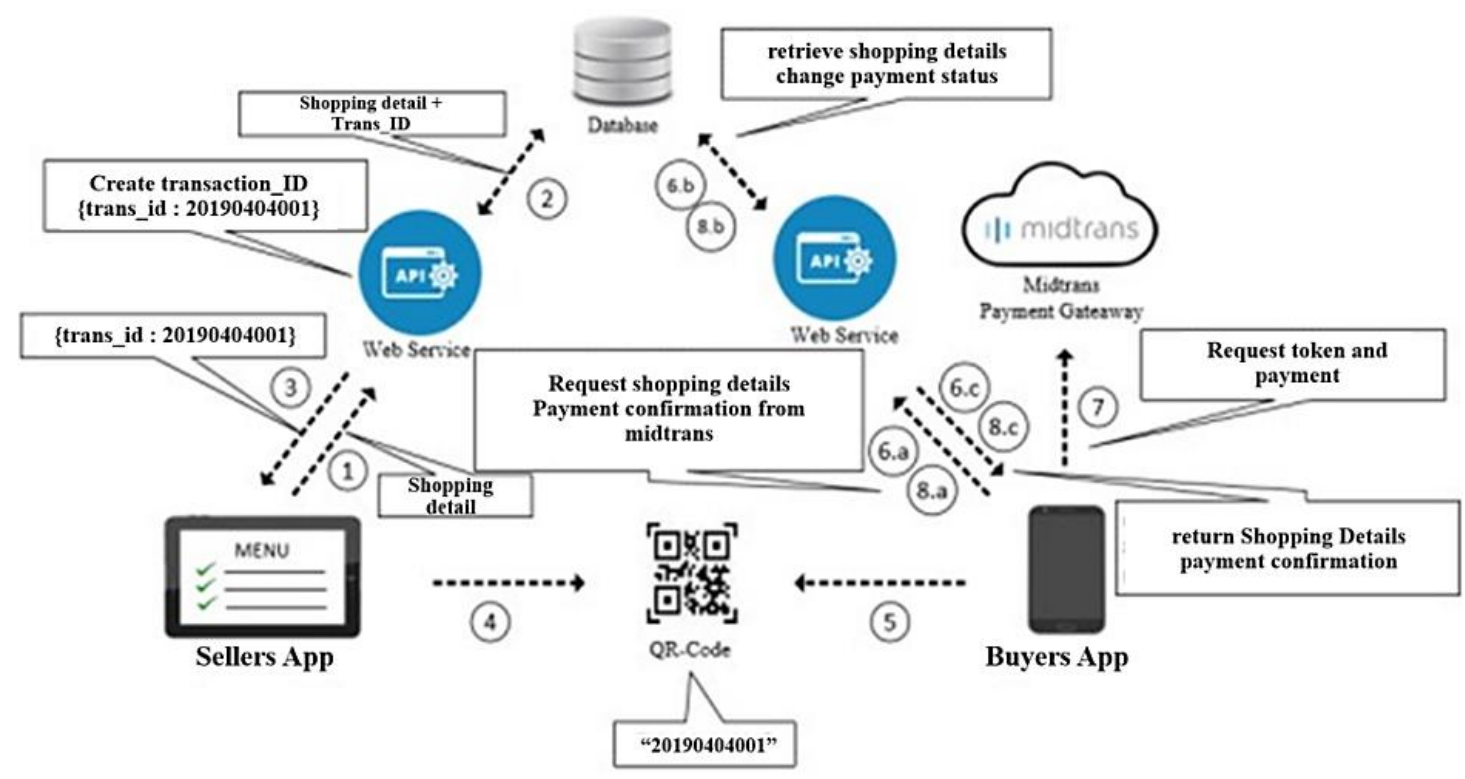

Figure 5. QR code analysis of contactless system

The payment gateway used in this system is the Midtrans payment gateway. Midtrans is used as an intermediary so the system can make payments using Go-Pay. The architectural description of how midtrans payment gateway and Go-Pay work can be seen in Figure 6.

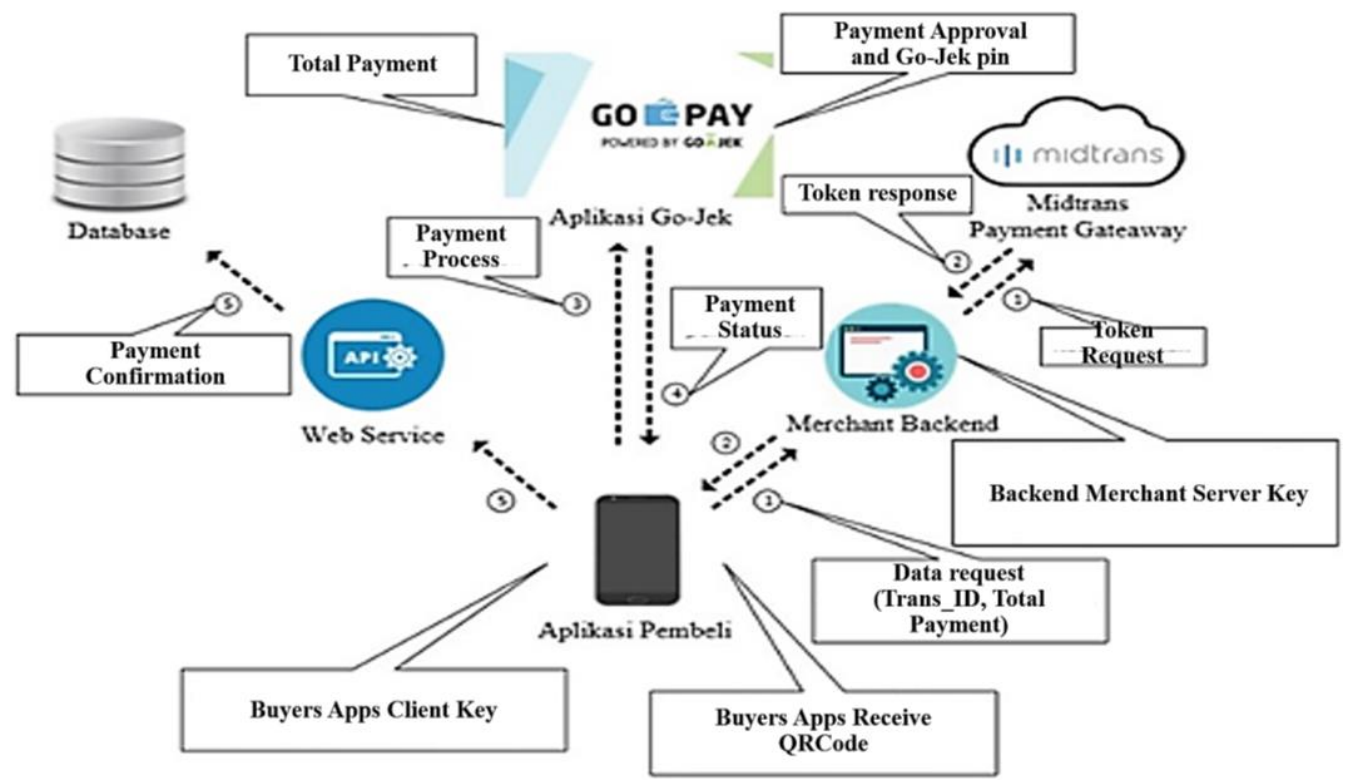

Figure 6. Payment gateway analysis of contactless system

The payment mechanism that occurs uses an authentication token by utilizing the client key and server key provided by the Midtran payment gateway. The transfer of payment transactions from the buyer's application to the Go-Jek application will be carried out directly when the buyer's application has received the transaction token from Midtrans.

Prototype mobile contactless transaction system in traditional markets to support the ... (Irawan Afrianto) 


\subsection{System implementation}

The interfaces implemented in the system built are divided into three different parts, namely: backend interfaces for a market manager: Figure 7 shows the application interface used by market managers to manage data sellers, kiosks, and financial transaction data in their market.

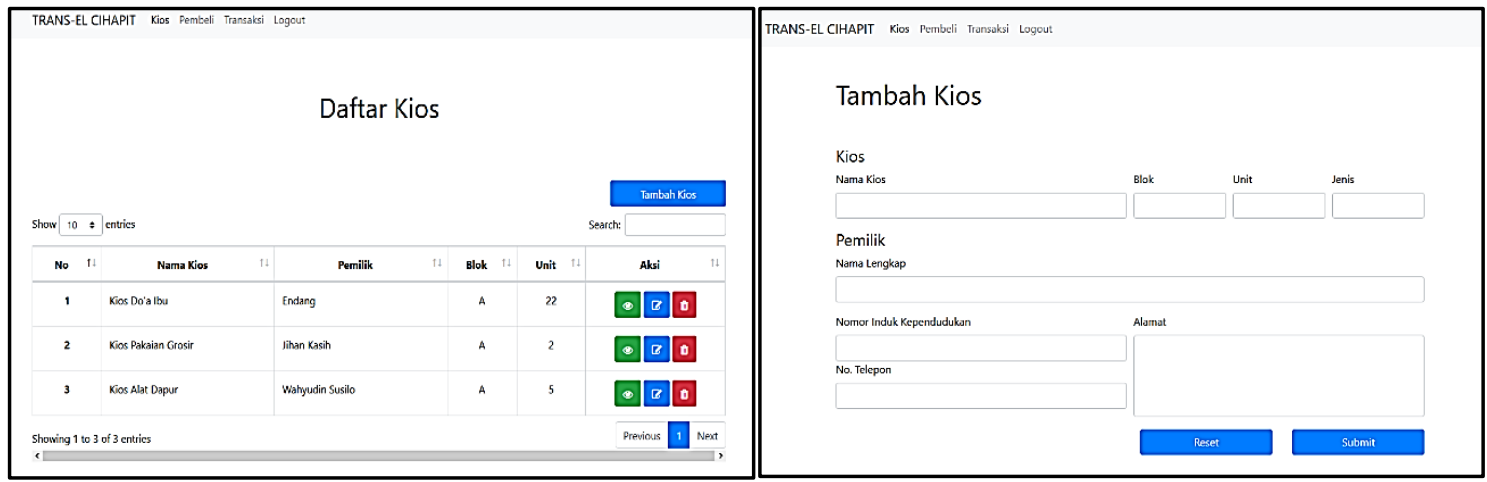

Figure 7. Backend application for market manager

Frontend application for sellers: Figure 8 shows the application interface from the seller's side. This interface is used to store data on products sold, prices, generate QR codes, and find out about financial transactions at the kiosk. Frontend application for buyers: Figure 9 shows the interface from the buyer's side. This interface is used to make transactions, scan the QR code of purchased goods, and pay for them using the e-wallet it owns.

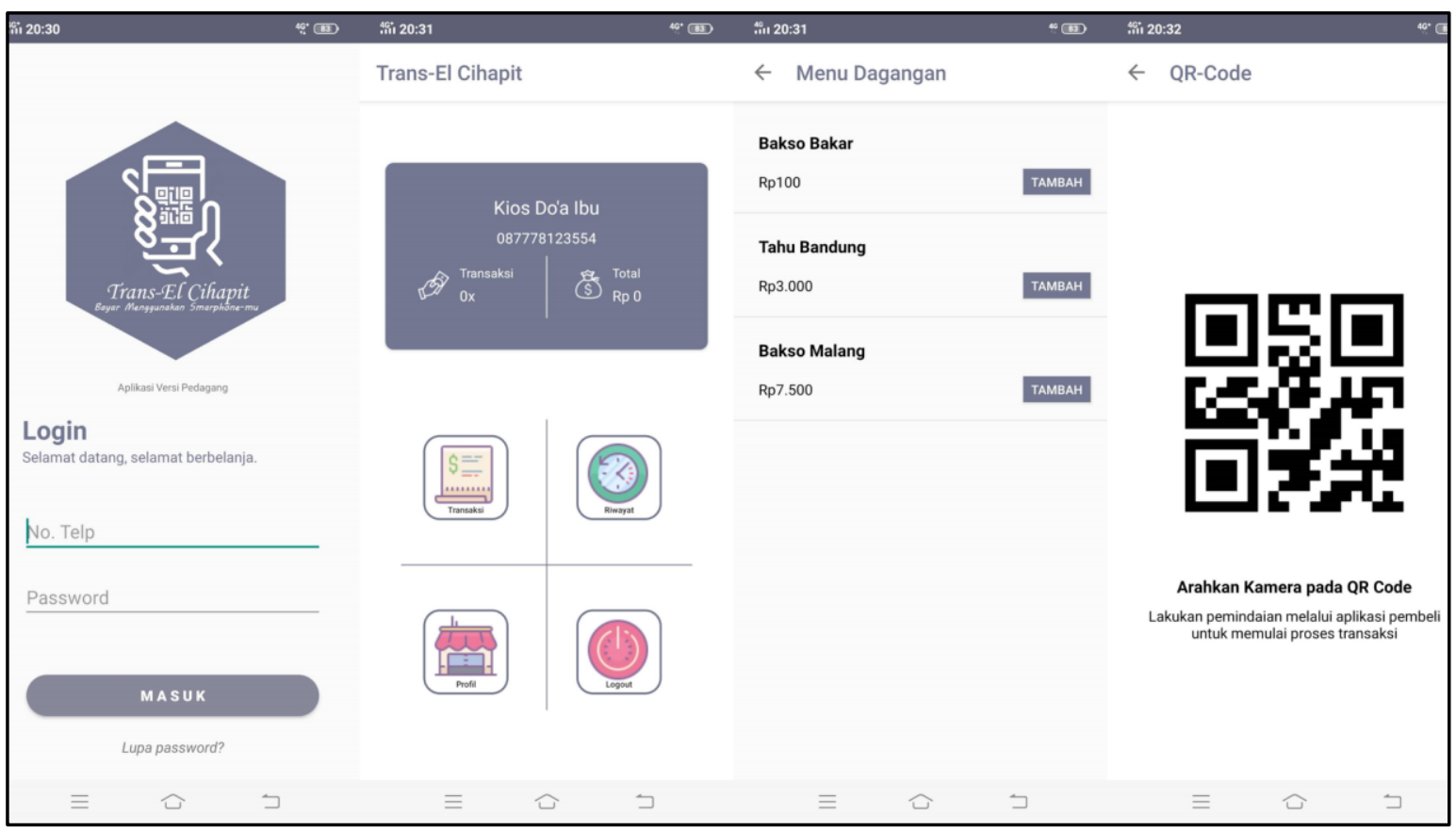

Figure 8. Frontend application for sellers 


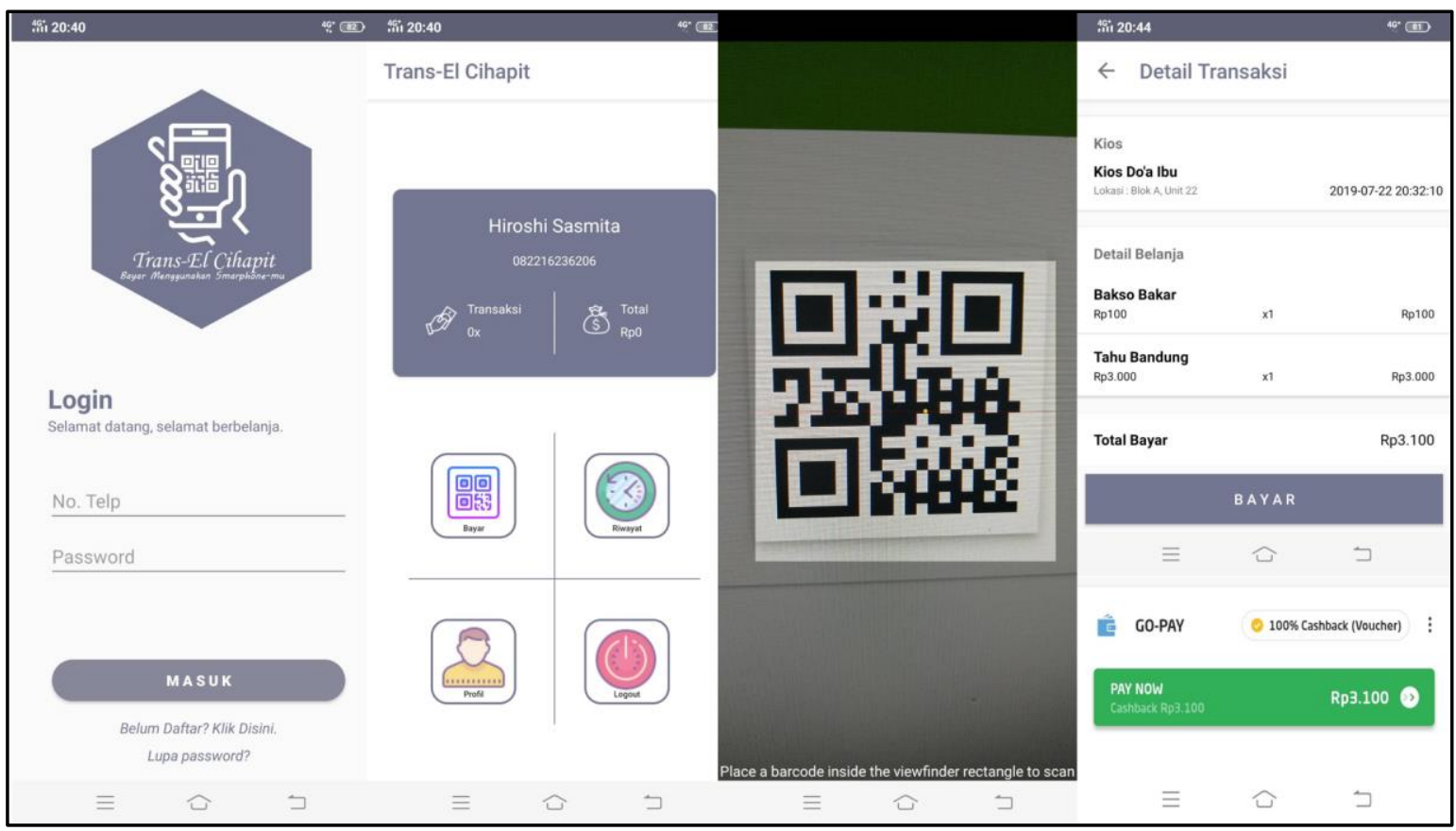

Figure 9. Frontend application for buyers

\subsection{Discussion}

Application testing is carried out using two test methods, namely the black box method and using a questionnaire. Blackbox testing is focused on system testing activities that are built to see the extent to which each function in the application has been running correctly, as expected, and free from errors. In addition to testing the application from a functional side, system testing is also carried out by users who will take advantage of the application. Acceptance of the use of applications is conducted with a questionnaire to obtain conclusions about acceptance of application use from the user's side [28]. The black box test results show that all functions from the perspective of market managers, sellers, and buyers have been able to run properly according to their functions and there are no errors in the transactions. Meanwhile, Figure 10 shows the results of the user acceptance test with a questionnaire, processed using a Linkert scale consisting of 5 intervals and 6 questions, the conclusion is that the average user acceptance, namely traders, is $86.04 \%$ and buyers are $89 \%$. This shows that the system has been very well received by its users. QRcode-based transaction modules and payments using e-wallet have worked well to provide contactless transaction services between sellers and buyers.

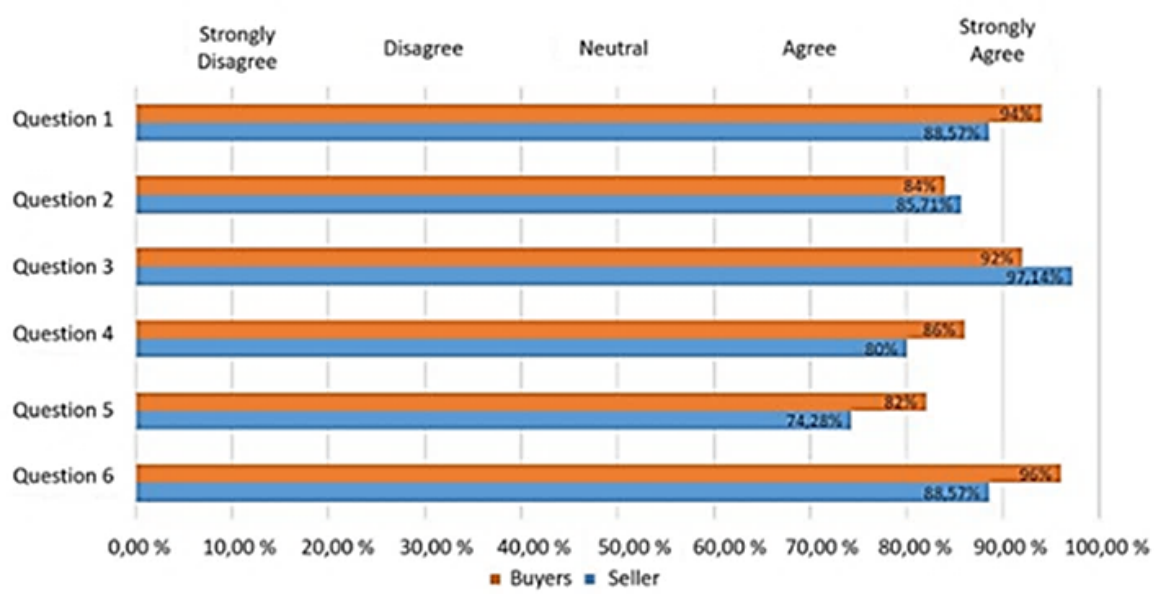

Figure 10. Result of user acceptance test 
The implementation of a payment gateway in the system makes this service have a transaction authentication process as well as ease of data processing, where the monitoring process can be carried out in real-time, making it easier to confirm every incoming fund, make sales reports, and find out customer details. However, the security of the electronic payment system is also something that needs to be considered by applying multiple security methods [29], as well as considering factors related to its advantages and disadvantages when used [30]. In addition, the prototype that was built still only uses one e-wallet service where this limits the flexibility of users in the payment process for their transactions, as well as the trust of users who are still unfamiliar with the use of e-wallet in their transactions.

\section{CONCLUSION}

The system that has been built can be used as a contactless transaction medium for transactions in the traditional market environment. Transaction activities can be done quickly and instantaneously by implementing the QR code feature and digital payments via smartphones. The use of alternative e-wallet payments and features of sharing transaction details between sellers and buyers can increase the convenience and speed of transactions. The existence of a payment gateway in the system makes it easier for users to find out transactions in real-time, create reports, to their financial transactions. The measurements taken also show acceptance of the usefulness of the system being built, as well as the optimism of its users to be able to take advantage of this system both technologically and functionally. However, this research still has the potential for development related to the strategy for implementing this technology so that the system and architecture can increase trust in its use, especially the use of digital payments which are still not commonly used by people in traditional market environments. As a result, digital transformation in traditional markets can be done using this prototype. QR code and the use of e-wallet can be done as an alternative transaction medium to replace traditional transactions. This study demonstrates how digital transformation may be used in traditional market transactions such as buying and selling. By utilizing this technology, conventional money exchanges can be minimized because they can be replaced with electronic payments so that the spread of the covid-19 virus pandemic can be reduced. The next step of this research is to develop a smart traditional market model where the digital transaction data that has been obtained will be used as the basic of market big data and its analysis using artificial intelligence and business intelligence mechanisms.

\section{ACKNOWLEDGEMENTS}

The researcher expresses his deepest gratitude to the sellers and buyers in Cihapit traditional market in Bandung who are willing to be a pilot project for system development and testing, as well as the Indonesian Computer University (UNIKOM) who provided funding assistance for this research.

\section{REFERENCES}

[1] N. N. Ardhiansyah and T. Mahendarto, "Revitalizing And Reimagining The Indonesian Traditional Market (Case Study: Salaman Traditional Market Indonesia)," IOP Conference Series: Earth and Environmental Science, vol. 436, no. 1, 2020, doi: 10.1088/1755-1315/436/1/012010.

[2] D. Ferricha and H. Fauzan, "How The Policy And Empowerment Of Traditional Markets In Indonesia?," International Journal Of Scientific \& Technology Research, vol. 9, no. 4, pp. 3649-3652, 2020.

[3] N. T. H. Giang, P. T. T. Hai, N. T. T. Tu and P. X. Tan, "Exploring The Readiness For Digital Transformation In A Higher Education Institution Towards Industrial Revolution 4.0.," International Journal of Engineering Pedagogy, vol. 11, no. 2, 2021

[4] S. J. Berman, "Digital Transformation: Opportunities To Create New Business Models," Strategy \& Leadership., vol. 40, no. 2, pp. 16-24, 2012, doi: /10.1108/10878571211209314 .

[5] C. Ebert and C. H. C. Duarte, "Digital Transformation.," Ieee Softw., vol. 35, no. 4, pp. 16-21, 2018.

[6] S. Kudyba, "Covid-19 And The Acceleration Of Digital Transformation And The Future Of Work," Information Systems Management, vol. 37, no. 4, pp. 284-287, 2020, doi: 10.1080/10580530.2020.1818903.

[7] Z. Allam, "The Forceful Reevaluation Of Cash-Based Transactions By Covid-19 And Its Opportunities To Transition To Cashless Systems In Digital Urban Networks," Surveying the Covid-19 Pandemic and its Implication, pp. 107-117, 2020, doi: 10.1016/B978-0-12-824313-8.00008-5.

[8] N. Iivari, S. Sharma and L. Ventä-Olkkonen, "Digital Transformation Of Everyday Life-How Covid-19 Pandemic Transformed The Basic Education Of The Young Generation And Why Information Management Research Should Care?," International Journal of Information Management, vol. 55, 2020, doi: 10.1016/j.ijinfomgt.2020.102183.

[9] I. Mustapha, N. T. Van, M. Shahverdi, M. I. Qureshi and N. Khan, "Effectiveness Of Digital Technology In Education During Covid-19 Pandemic. A Bibliometric Analysis.," International Journal of Interactive Mobile Technologies, vol. 15, no. 8, 2021.

[10] H. M. Aji, I. Berakon and M. M. Husin, “Covid-19 And E-Wallet Usage Intention: A Multigroup Analysis Between 
Indonesia And Malaysia," Cogent Business \& Management, vol. 7, no. 1, pp. 1-6, 2020, doi: 10.1080/23311975.2020.1804181.

[11] Y. Zhu, "The Development Of E-Commerce Practice Teaching Software Based On Online Payment And Settlement," International Journal of Online Engineering (iJOE), vol. 10, no. 2, pp. 4-9, 2014.

[12] T. Pambudi, A. Raden and S. T. Rahadi, "The Impact Of Pandemic Covid-19 On Digital Payment: Case Study On Electronic Money In Indonesia," International Journal of Advanced Research in Economics and Finance, vol. 3, no. 1, pp. 70-79, 2021.

[13] D. A. Pramesti, E. K. Pratiwi, Z. B. Pambuko, F. Medias, A. Triyanto and N. Usman, "Digital Payment: User Experience In Indonesia,” Test Engineering \& Management, pp. 22536-22541, 2020.

[14] E. Husni and A. Ariono, "Development of integrated mobile money system using Near Field Communication (NFC)," 2014 8th International Conference on Telecommunication Systems Services and Applications (TSSA), 2014, pp. 1-6, doi: 10.1109/TSSA.2014.7065959.

[15] Z. Bezovski, "The Future Of The Mobile Payment As Electronic Payment System," European Journal of Business and Management, vol. 8, no. 8, pp. 127-132, 2016.

[16] A. Wibiyanto and I. Afrianto, "Qr Code And Transport Layer Security For Licensing Documents Verification," IOP Conference Series: Materials Science and Engineering, vol. 407, no. 1, 2018, doi: 10.1088/1757$899 x / 407 / 1 / 012069$

[17] S. K. Chatterjee, S. Saha, Z. Khalid, H. N. Saha, P. Paul and R. Karlose, "Space effective and encrypted QR code with sender authorized security levels," 2018 IEEE 8th Annual Computing and Communication Workshop and Conference (CCWC), 2018, pp. 439-443, doi: 10.1109/CCWC.2018.8301640.

[18] W. Widyasari, H. Sutopo and M. Agustian, "Qr Code-Based Learning Development: Accessing Math Game For Children Learning Enhancement," International Journal of Interactive Mobile Technologies (iJIM), 2019, doi: 10.3991/ijim.v13i11.10976.

[19] N. Anwar, R. Rasjidin, D. S. Najoan, C. Rolando and H. L. H. S. Warnars, "E-Payment For Jakarta Smart Public Transportation, Using The Point System For E-Commerce," Journal Of Physics: Conference Series, vol. 1477, no. 2, 2020, doi: 10.1088/1742-6596/1477/2/022035.

[20] H. L. H. S. Warnars, Y. Lanita, A. Prasetyo and R. Randriatoamanana, "Smart Integrated Payment System For Public Transportation In Jakarta," Bulletin of Electrical Engineering and Informatics, vol. 6, no. 3, pp. 241-249, 2017, doi: 10.11591/eei.v6i3.655.

[21] A. A. Saleem, H. U. R. Siddiqui, R. Shafique, A. Haider and M. Ali, "A Review On Smart Iot Based Parking System," International Conference On Soft Computing And Data Mining, Springer, Cham, pp. 264-273, 2020, doi: 10.1007/978-3-030-36056-6_26.

[22] S. A. A. Tarmazi, W. R. W. Ismail, N. A. S. N. Azmin and A. R. A. Bakar, "Consumer Purchase Intention Toward Online Food Delivery Service: The Implication For Future Research," Malaysian Journal of Social Sciences and Humanities (MJSSH), vol. 6, no. 9, pp. 347-354, 2021, doi: 10.47405/mjssh.v6i9.972.

[23] V. Chang, W. Chen, Q. A. Xu and C. Xiong, "Towards The Customers' Intention To Use Qr Codes In Mobile Payments," Journal of Global Information Management (JGIM), vol. 29, no. 6, pp. 1-21, 2021, doi: 10.4018/JGIM.20211101.oa37.

[24] R. Liu, J. Wu and G. F. Yu-Buck, "The Influence Of Mobile Qr Code Payment On Payment Pleasure: Evidence From China," International Journal of Bank Marketing, vol. 39, no. 2, pp. 337-356, 2021, doi: 10.1108/IJBM-112020-0574.

[25] G. F. Djayapranata and A. Setyawan, "Trust Or Usefulness? Qr Code Payment Among Millennials In A Disrupted Market," 18th International Symposium on Management (INSYMA 2021). Atlantis Press, pp. 194-199, 2021.

[26] I. Afrianto, A. Heryandi, A. Finandhita and S. Atin, "E-Document Autentification With Digital Signature Model For Smart City In Indonesia"Journal of Engineering Science and Technology, vol. 15, pp. 28-35, 2020.

[27] A. Heryandi and I. Afrianto, "Online Diploma Supplement Information System Modelling For Indonesian Higher Education Institution," IOP Conference Series: Materials Science And Engineering, vol. 662, no. 2, 2019, doi: 10.1088/1757-899x/662/2/022092.

[28] S. Basak And M. S. Hosain, "Software Testing Process Model From Requirement Analysis To Maintenance," International Journal of Computer Applications, vol. 107, no. 11, 2014.

[29] G. Ali, M. Ally Dida and A. Elikana Sam, "Two-Factor Authentication Scheme For Mobile Money: A Review Of Threat Models And Countermeasures," Future Internet, vol. 12, no. 10, 2020, doi: 10.3390/fi12100160.

[30] S. Yakean, "Advantages And Disadvantages Of A Cashless System In Thailand During The Covid-19 Pandemic," The Journal of Asian Finance, Economics, and Business, vol. 7, no. 12, pp. 385-388, 2020, doi: 10.13106/jafeb.2020.vol7.no12.385. 


\section{BIOGRAPHIES OF AUTHORS}
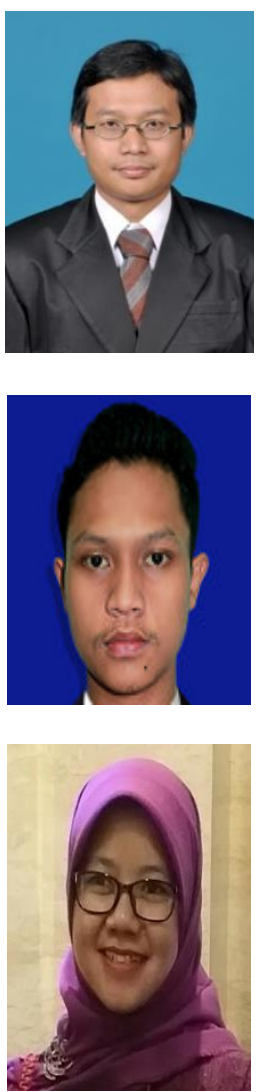

Irawan Afrianto is a lecturer at the Department of Informatics, Universitas Komputer Indonesia (UNIKOM) Bandung. Currently completing the Computer Sci-ence Doctoral program at IPB University Bogor with the research field of Blockchain Technology in agroindustry.

Mouhamad Hatta Hiroshi Sasmita is an alumni of Informatics Department, Universitas Komputer Indonesia (UNIKOM) Bandung. Currently working as an Android Developer at PT. Nostra Technology.

Sufa Atin is a lecturer at Informatics Department, Universitas Komputer Indonesia (UNIKOM) Bandung. The areas of research undertaken are in information systems, software project management and socio-informatics. 